Boise State University

ScholarWorks

Geosciences Faculty Publications and

Presentations

Department of Geosciences

4-5-2016

\title{
Aquifer Arsenic Cycling Induced by Seasonal Hydrologic Changes within the Yangtze River Basin
}

\author{
Michael V. Schaefer \\ Stanford University \\ Samantha C. Ying \\ University of California - Riverside \\ Shawn G. Benner \\ Boise State University \\ Yanhua Duan \\ China University of Geosciences \\ Yanxin Wang \\ China University of Geosciences
}

See next page for additional authors

This document was originally published in Environmental Science \& Technology by the American Chemical Society under an ACS AuthorChoice License (http://pubs.acs.org/page/policy/authorchoice_termsofuse.html). Copyright restrictions may apply. doi: $10.1021 /$ acs.est.5b04986 
Authors

Michael V. Schaefer, Samantha C. Ying, Shawn G. Benner, Yanhua Duan, Yanxin Wang, and Scott Fendorf

This article is available at ScholarWorks: https://scholarworks.boisestate.edu/geo_facpubs/298 


\title{
Aquifer Arsenic Cycling Induced by Seasonal Hydrologic Changes within the Yangtze River Basin
}

\author{
Michael V. Schaefer, ${ }^{\dagger}$ Samantha C. Ying, ${ }^{\ddagger}$ Shawn G. Benner, ${ }^{\S}$ Yanhua Duan, " Yanxin Wang, \\ and Scott Fendorf*, ${ }^{*}$ \\ ${ }^{\dagger}$ Earth System Science Department, Stanford University, Stanford, California 94305, United States \\ ${ }^{\ddagger}$ Environmental Sciences Department, University of California - Riverside, Riverside, California 92521, United States \\ ${ }^{\S}$ Department of Geosciences, Boise State University, Boise, Idaho 83725, United States \\ "State Key Laboratory of Biogeology and Environmental Geology, China University of Geosciences, Wuhan, Hubei 430074, People's \\ Republic of China
}

\section{Supporting Information}

ABSTRACT: Consumption of groundwater containing $>10 \mu \mathrm{g} \mathrm{L}^{-1}$ arsenic (As) adversely impacts more than 100 million people worldwide. Multiyear trends in aquifer As concentrations have been documented, but strong seasonal variations are not commonly observed. Here we report dramatic seasonal changes in As concentrations and aquifer chemistry within the Jianghan Plain of the Yangtze River, China. At some wells, concentrations fluctuate by more than an order of magnitude within a single year (100-1200 $\mu \mathrm{g}$ $\left.\mathrm{L}^{-1}\right)$. Groundwater extraction and sustained water levels of surface channels during the dry season induces a strong downward hydraulic gradient, seasonally supplying oxidizing (oxygen, nitrate) water to the otherwise anoxic aquifer. Oxygen and/or nitrate addition promotes a transient drop in As concentrations for 1-3 months. When recharge ceases, reducing, low-arsenic conditions are reestablished by reactive, endogenous organic carbon. Temporal variability in As concentrations is especially problematic because it increases the probability of false-negative well testing during low-arsenic seasons. However, periods of low As may also provide a source of less toxic water for irrigation or other uses. Our results highlight the vulnerability and variability of groundwater resources in the Jianghan Plain and other inland basins within Asia to changing geochemical conditions, both natural and anthropogenic, and reinforce that continued monitoring of wells in high-risk regions is essential.

\section{INTRODUCTION}

Groundwater arsenic (As) contamination is a global problem affecting the health of millions of people through arsenicosis and increased risk for cancers ${ }^{1}$ and cardiovascular disease, ${ }^{2}$ as well as decreased immune resistance to infections such as the $\mathrm{H} 1 \mathrm{~N} 1$ virus. $^{3}$ In South and Southeast Asia, geogenic arsenic contaminates large portions of the aquifers of the Brahmaputra/Ganges, Mekong, Irrawaddy, and Red River Deltas. ${ }^{4}$ Arsenic in these deltas is derived from a common Himalayan source $^{5,6}$ and deposited in low-lying regions where reduction of As-bearing iron ( $\mathrm{Fe}$ ) minerals liberates As from the solid phase, transferring As to groundwater that is extracted for drinking through shallow tubewells. ${ }^{7,8}$ Arsenic concentrations in deltas across Asia commonly exceed the World Health Organization (WHO) drinking water standard of $10 \mu \mathrm{g} \mathrm{L}^{-1}$.,5

China contains some of the most populated regions at risk of exposure to As contaminated groundwater. Current estimates of the Chinese population exposed to elevated arsenic concentrations, however, vary widely, ranging from 0.58 million $^{9}$ and 1.85 million $^{10}$ to as many as 19.6 million

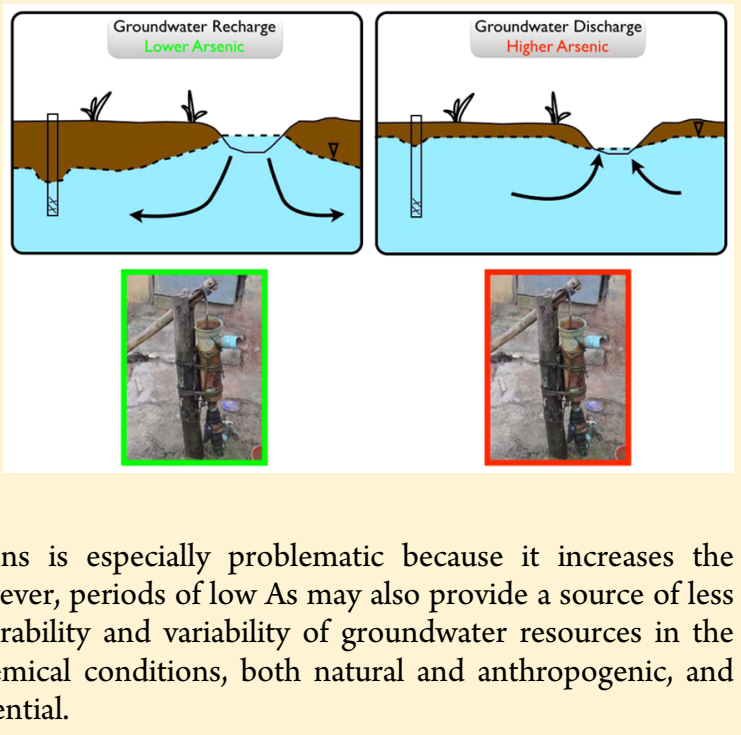

individuals. ${ }^{11}$ Although arsenicosis was first reported in China in $1980,{ }^{12}$ information on groundwater arsenic contamination and exposure were not widely distributed outside of China until recently. Additionally, much of the current research on Ascontaminated groundwater has focused on inland basins of arid regions in Northern China ${ }^{9,10,13}$ where organic-rich deposits and alkaline waters have been reported to cause As desorption from the solid phase. Recent studies have also identified As contamination throughout the Jianghan Plain, an inland depositional basin along the Yangtze River. ${ }^{14}$

An outstanding question for mitigating groundwater arsenic exposure is determining how concentrations vary temporally. A recent study ${ }^{15}$ in New England, U.S., shows that seasonal variability in As concentrations may have been underestimated in previous data sets and may be a significant issue in accurately

Received: October 11, 2015

Revised: January 17, 2016

Accepted: January 20, 2016

Published: January 20, 2016 


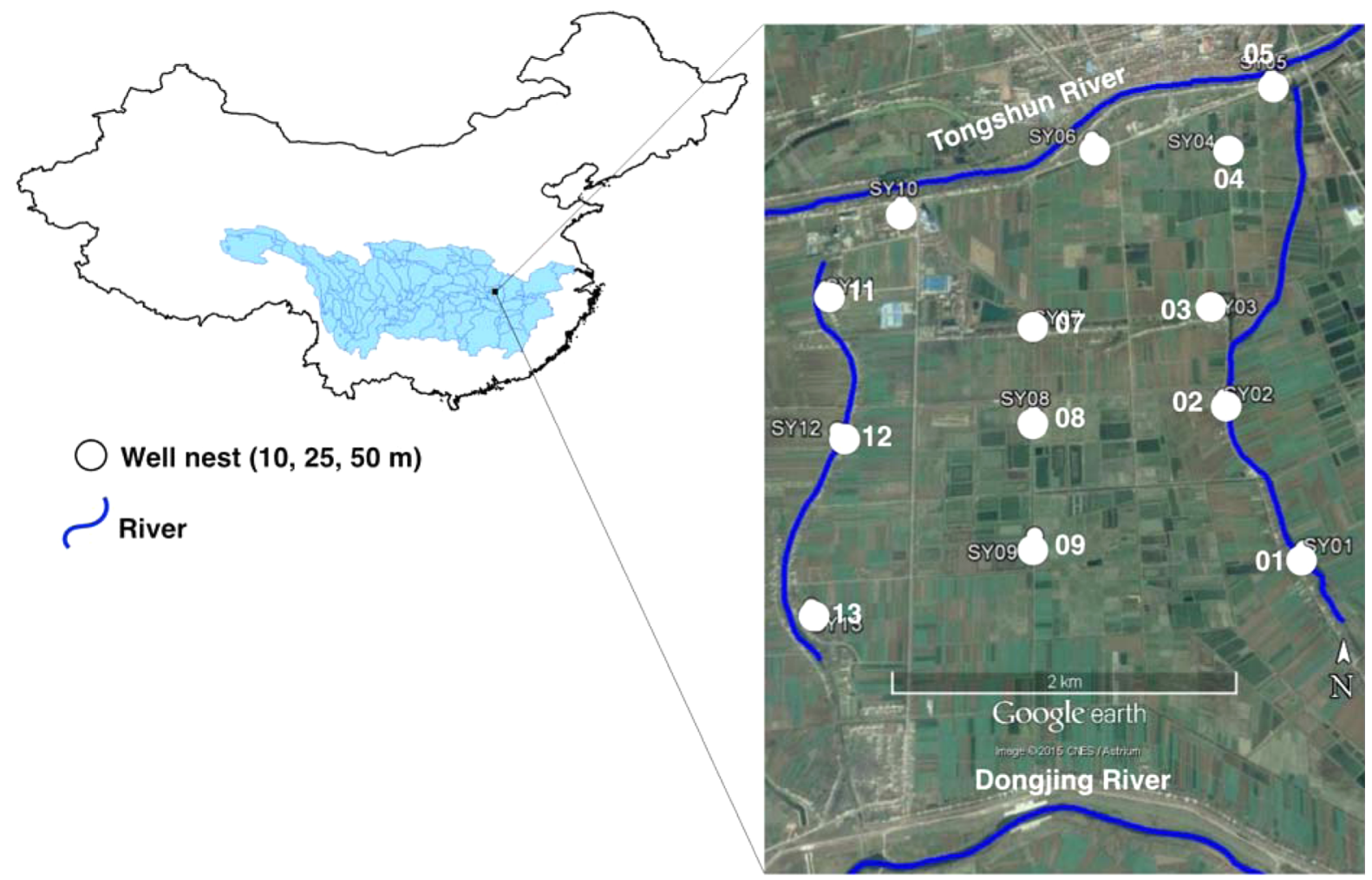

Figure 1. Map of China and the Yangtze River Basin. The location of the monitoring area is indicated by a black square, and the major surface waterways and monitoring wells are shown by the Google Earth satellite image. Each groundwater monitoring site includes nested wells screened at 10,25 , and $50 \mathrm{~m}$. Blue lines highlight major rivers that bound the field area, and the scale bar is $2 \mathrm{~km}$. Yangtze Basin data were obtained from the World Resources Institute. ${ }^{16}$

modeling As concentrations. Additional studies in Oregon, U.S., ${ }^{17}$ Vietnam, ${ }^{18}$ and Cambodia ${ }^{19,20}$ also show seasonal variation in groundwater As. The magnitude of changes in As concentrations varies across study areas. In New England, a threshold of $\pm 4 \mu \mathrm{g} \mathrm{L}^{-1}$ was used to determine whether a change occurred between samples but concentrations exceeded $100 \mu \mathrm{g} \mathrm{L}^{-1}$ in $<1 \%$ of the over 2000 measurements in the study. ${ }^{15}$ Arsenic concentrations changed by $\sim 400 \mu \mathrm{g} \mathrm{L}^{-1}$ within a year in both surficial porewater and deeper groundwater in the Mekong Delta, where As concentrations average $500 \mu \mathrm{g} \mathrm{L}^{-1}$ and can exceed $1000 \mu \mathrm{g} \mathrm{L}^{-1}$ in some wells. ${ }^{19}$ The strongest temporal changes were observed near the banks of the Mekong River and attributed to changes in horizontal hydraulic gradients in the aquifer. In contrast, studies in Nevada, U.S., ${ }^{21}$ and Bangladesh ${ }^{22}$ have observed limited seasonal fluctuations in As concentrations. In Bangladesh, ${ }^{22}$ wells were selected for initial As concentrations $<50 \mu \mathrm{g} \mathrm{L}^{-1}$ while in Nevada ${ }^{21}$ As concentrations averaged $73 \mu \mathrm{g} \mathrm{L}^{-1}$ but included wells with As concentrations that exceeded $3000 \mu \mathrm{g} \mathrm{L}^{-1}$. In Nevada, ${ }^{21} 43 \%$ of the wells showed variation in As concentrations, but half increased during the dry season while half increased during the wet season. The focus of most temporal studies has been on multiyear trends ${ }^{23}$ or to discern whether shallow groundwater with high As concentrations can migrate and contaminate low-arsenic, deeper groundwater over time. $^{24-26}$

In the present study, we examine temporal trends in groundwater arsenic concentrations reported within the Jianghan Plain of the Yangtze River, ${ }^{27}$ a recently discovered region of As contaminated groundwater with depositional characteristics similar to many other As-affected areas of Asia. ${ }^{14}$
Our objective was to determine the mechanisms underlying the seasonal fluctuations in arsenic concentrations and thus their propensity to occur in other regions. Our results document strong seasonal shifts in groundwater arsenic resulting from hydrologic gradients that induce radically different biogeochemical aquifer conditions, illustrating the need to increase monitoring frequency as well as the potential to exploit lowarsenic periods for extraction.

\section{MATERIALS AND METHODS}

Field Area. The Yangtze River (Changjiang) is the longest river in Asia flowing $\sim 6400 \mathrm{~km}$ from the Qinghai-Tibet Plateau to the East China Sea and draining an area of approximately 1.8 million $\mathrm{km}^{2}$. Downstream of the Three Gorges area, the river empties into an alluvial basin, the Jianghan Plain, built of sediment derived from the Yangtze and Han Rivers, encompassing an area of $>55000 \mathrm{~km}^{2} .^{28}$ The Plain's climate is subtropical monsoon and was historically dominated by a substantive system of lakes covering $\sim 7 \%$ of the land surface, although drainage for land reclamation decreased the lake area from 3885 to $1839 \mathrm{~km}^{2}$ (a decrease of 53\%) between 1950 and $1978 .^{28}$ The field area in this study is mainly agricultural and includes a large area of aquaculture ponds; however, a large metals refining plant is located within the area. Both irrigated fields and ponds are dominantly supplied with surface water. An overview of the field site $\left(30.15^{\circ} \mathrm{N}, 113.66^{\circ} \mathrm{E}\right)$ and monitoring well locations is provided in Figure 1.

Well Installation. Drilling and well installation occurred in November 2011. Nests of three wells $<1 \mathrm{~m}$ apart were installed at 13 locations within the $\sim 10 \mathrm{~km}^{2}$ field area comprising 39 total monitoring wells (Figure 1). Each location included wells 
with a $1 \mathrm{~m}$ screen centered at 10,25 , and $50 \mathrm{~m}$. Wells were drilled using either a Geoprobe 6620DT direct push drill rig or a rotary drill method. Sediment texture was logged for each well during drilling, and general lithology of the area is fine-grained silts and clays covering the top $\sim 18 \mathrm{~m}$ and fine to coarse sand below this depth (Supporting Informaton (SI) Figure SI-1). Polyvinyl chloride (PVC) pipe with a $1 \mathrm{~m}$ sliced screen was inserted into the drill hole. The annulus was backfilled with clean coarse sand to cover the well screen and then topped with $1 \mathrm{~m}$ of bentonite to seal the well screen from surface water. The remaining fill was with native sediment. Each well was mounted with a concrete apron and sealed with a locked iron cover. Immediately after installation, wells were pumped until clear water was obtained and allowed to mature for six months prior to further sampling in May 2012. Groundwater chemistry was monitored monthly at all 39 wells and at least two surface water bodies. Pump tests were performed in September 2014 to check for leaking and short-circuiting wells. Details of the tests and results for a pump test at well nest SY13 are provided in SI Figure SI-2.

Water Level Monitoring. Well water levels were monitored twice per month using an electronic water sensor and translated to relative positions for the field area using surveyed points. The average of three water depth measurements was recorded in the field. These measurements were converted to water level heights by subtracting them from the surveyed well casing elevation. Surface water levels were measured relative to fixed points of known elevation. Potential flow between surface water and groundwater or between wells at different depths was determined by subtracting water level elevations. When determining surface water and groundwater differences, the average of the Tongshun (north) and Dongjing (south) rivers (Figure 1) was used for the surface water elevation because the water levels in these rivers feed irrigation canals and aquaculture ponds throughout the field site and are most indicative of regional surface water trends.

Chemical and Isotopic Analysis. After water level measurements were recorded, wells were purged and temperature $\left( \pm 0.1{ }^{\circ} \mathrm{C}\right.$ ) and oxidation-reduction potential (ORP, \pm $0.1 \mathrm{mV}$ ) were measured in the field using a Hach HQ40D multimeter. ORP measured on the HQ40D relative to $\mathrm{Ag}^{+}$/ $\mathrm{AgCl}$ was converted to the ORP of standard hydrogen electrode, Eh, by adding +240-251 mV depending on the measured water temperature. Purging volumes were at least three well volumes or until temperature and ORP measurements stabilized. Arsenic concentrations were determined from field-acidified samples with a Titan 930 hydride generation atomic fluorescence spectrophotometer (HG-AFS). Select samples were also analyzed for arsenite and arsenate speciation using high pressure liquid chromatography linked to an inductively coupled plasma mass spectrometer (HPLC-ICP$\mathrm{MS}$ ). Anion concentrations (chloride) were analyzed using a Dionex 2500 ion chromatograph (IC). Aqueous Fe(II) and sulfide concentrations were measured in the field using a Hach 2800 portable spectrophotometer and $\mathrm{Hach}$ reagent kits. Hydrogen $(\mathrm{H})$ and oxygen $(\mathrm{O})$ isotopes were measured using a gas stable isotope mass spectrometer (MAT253, Finnigan, Germany). The precision for $\delta^{2} \mathrm{H}$ and $\delta^{18} \mathrm{O}$ were $\pm 1.0 \%$ and $\pm 0.1 \%$, respectively.

Sediment Incubations. Sediment microcosms were performed in duplicate to track arsenic release from sediments recovered during drilling at site SY03 (Figure 1). Sediment cores were sealed with paraffin wax, frozen, and stored in gastight boxes with Anaeropack (Mitsubishi) oxygen scavenging packs and transferred to Stanford. All incubations were performed in an anoxic chamber $\left(95 \% \mathrm{~N}_{2}\right.$ and $5 \% \mathrm{H}_{2}$ atmosphere). Twenty $\mathrm{g}$ of anoxic sediment from each sampled depth were suspended in $100 \mathrm{~mL}$ of anoxic DI water in a sealed serum vial. Five $\mathrm{mL}$ aliquots of homogenized sediment-water slurry were sampled daily for 4 days and filtered with a $0.2 \mu \mathrm{m}$ syringe filter, after which major elements were measured with inductively coupled plasma optical emission spectroscopy (ICP-OES).

\section{RESULTS}

Surface and Well Water Levels. Surface water levels at the field site fluctuate 5-8 m annually (Figure 2) and are

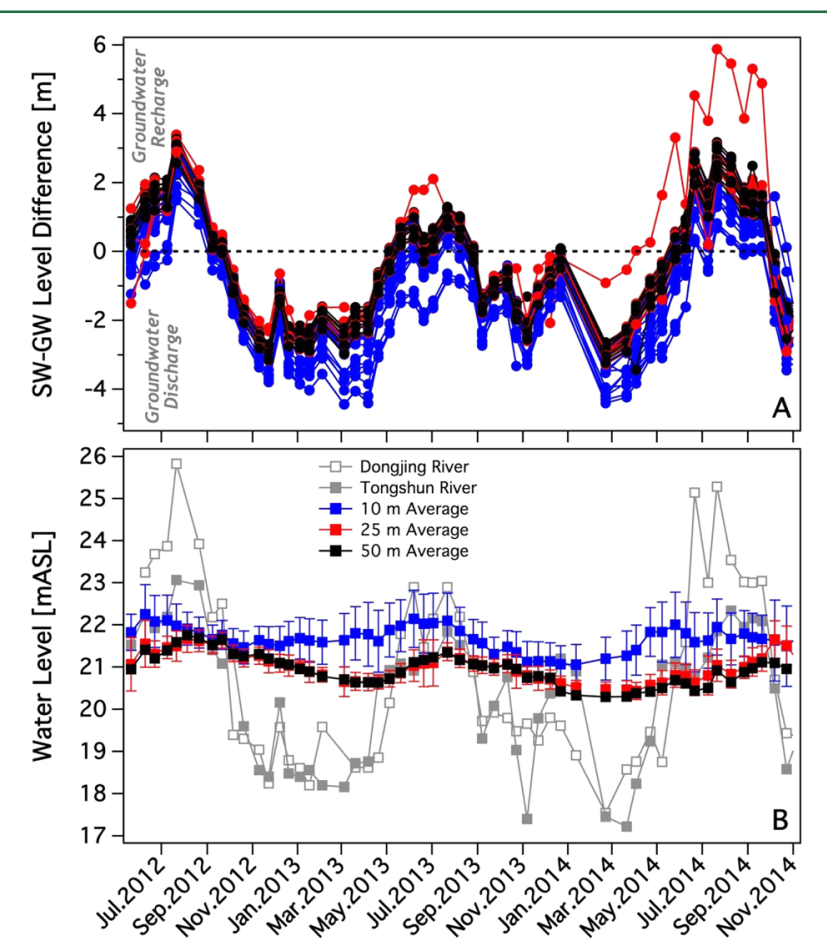

Figure 2. Water levels in wells and rivers within the field area. (a) Difference of the average surface water (SW) level and groundwater (GW) level in the aquifer. Ten $\mathrm{m}$ wells are blue, $25 \mathrm{~m}$ wells are red, and $50 \mathrm{~m}$ wells are black. Positive values indicate that the surface water level is higher, and flow is from surface water to the aquifer (groundwater recharge). Negative values indicate flow from wells to the surface (groundwater discharge). (b) Water levels measured in the Dongjing and Tongshun Rivers plotted with the average water level in 10,25 , and $50 \mathrm{~m}$ wells. Error bars represent one standard deviation ( $n$ $=13$ wells for each depth).

closely tied to monsoon rains (SI Figure SI-3). Average well water levels follow a trend similar to surface water, but the magnitude of their fluctuations is approximately $1 \mathrm{~m}$ and the timing of falling and rising well water levels lags surface water changes (Figure 2). The consequence of these fluctuations is an annual reversal of groundwater flow gradient that is dictated by changes in surface water level (Figure 2). During the wet summer monsoon when surface water levels are higher than groundwater levels, a groundwater recharge flow gradient develops; groundwater pumping further maintains this strong downward gradient. During drier, winter months (nominally September to April), surface water levels drop below 
groundwater levels, and groundwater flow reverses and moves toward surface waters.

Although variable on an individual well nest basis, average water levels for the shallow $10 \mathrm{~m}$ wells are higher than the deeper 25 or $50 \mathrm{~m}$ wells, indicating a net downward gradient throughout the year (Figure 2B). This gradient increases during the dry season as water levels in the deeper wells fall faster than $10 \mathrm{~m}$ wells. Water levels in the 25 and $50 \mathrm{~m}$ wells are similar in nearly all measurements, indicating that the aquifers at 25 and $50 \mathrm{~m}$ are hydraulically connected. Groundwater levels are provided for each well nest individually in SI Figures SI-11 to SI-23.

Surface-Groundwater Tracers. $\delta^{2} \mathrm{H}$ and $\delta^{18} \mathrm{O}$ values were measured at well nests SY03, SY05, and SY07 from June 2012 to March 2014. When a strong downward gradient is observed (June-October 2012; May-August 2013), values of $\delta^{18} \mathrm{O}$ increase, indicating a water composition more similar to surface water (SI Figures SI-4 and SI-5). When the gradient reverses and the flow gradient is from groundwater to surface water, $\delta^{18} \mathrm{O}$ values decrease (more negative). The time lag between gradient direction and $\delta^{18} \mathrm{O}$ values is $0-2$ months, suggesting rapid delivery of surface water to the deeper portions of the aquifer.

Surface water temperatures fluctuate seasonally and range from 5 to $34{ }^{\circ} \mathrm{C}$. Well water temperatures follow a similar seasonal trend but are dampened relative to surface water temperature, ranging between 13 and $26{ }^{\circ} \mathrm{C}$ (SI Figure SI-6). There is no obvious lag between surface and groundwater temperature trends.

The rapid rise in surface water levels in December is followed by a sharp (nearly 100-fold) increase in $\mathrm{Cl}^{-}$concentration in the Tongshun River, which bounds the north side of the field site (SI Figure SI-7). The source of the $\mathrm{Cl}^{-}$is suspected to be industrial; it serves as a conservative tracer for tracking surfacegroundwater interactions. Chloride concentration in the $25 \mathrm{~m}$ well at SY03 increases a month after the spike in surface water (SI Figure SI-7). Similarly timed seasonal changes in groundwater $\mathrm{Cl}^{-}$concentration are observed throughout the field site.

Arsenic Concentrations. During the 31 month period from May 2012 to November 2014, arsenic concentrations in groundwater of the 39 measured wells averaged $62 \mu \mathrm{g} \mathrm{L}^{-1}$ and ranged from $<1$ to $1200 \mu \mathrm{g} \mathrm{L}^{-1}(n=1092)$. Arsenic concentrations separated by well depth (Figure 3 ) show that the average and median As concentrations are highest in the 25 $\mathrm{m}$ wells, consistent with studies in Bangladesh where aqueous As concentrations generally reach a maximum at $20-30 \mathrm{~m}$ depth. ${ }^{29,30}$ Both the mean $\left(24,127,37 \mu \mathrm{g} \mathrm{L}^{-1}\right)$ and median (14, 68, $\left.37 \mu \mathrm{g} \mathrm{L}^{-1}\right)$ As concentration exceed China's drinking water standard of $10 \mu \mathrm{g} \mathrm{L}^{-1}$ for 10,25 , and $50 \mathrm{~m}$ wells, respectively (Figure 3).

Arsenic concentrations range over 3 orders of magnitude within the $\sim 10 \mathrm{~km}^{2}$ field site, and well depth alone does not account for these variations. Similar to previous studies, ${ }^{31}$ we found that As concentrations varied spatially across the field site, with the highest concentration observed at $25 \mathrm{~m}$ in well nest SY03 (Figure 4). Arsenic concentrations also varied seasonally across the field area; the most extreme case occurring at the $25 \mathrm{~m}$ well at SY03 when As concentrations increased from 100 to $1200 \mu \mathrm{g} \mathrm{L}^{-1}$ between May and July 2013 (Figure 4). In each year from 2012 to 2014, As concentrations dropped below $160 \mu \mathrm{g} \mathrm{L}^{-1}$ for at least one monthly measurement (May 2012, May 2013, March 2014) and reached a maximum value above $1000 \mu \mathrm{g} \mathrm{L}^{-1}$ for at least one monthly measurement

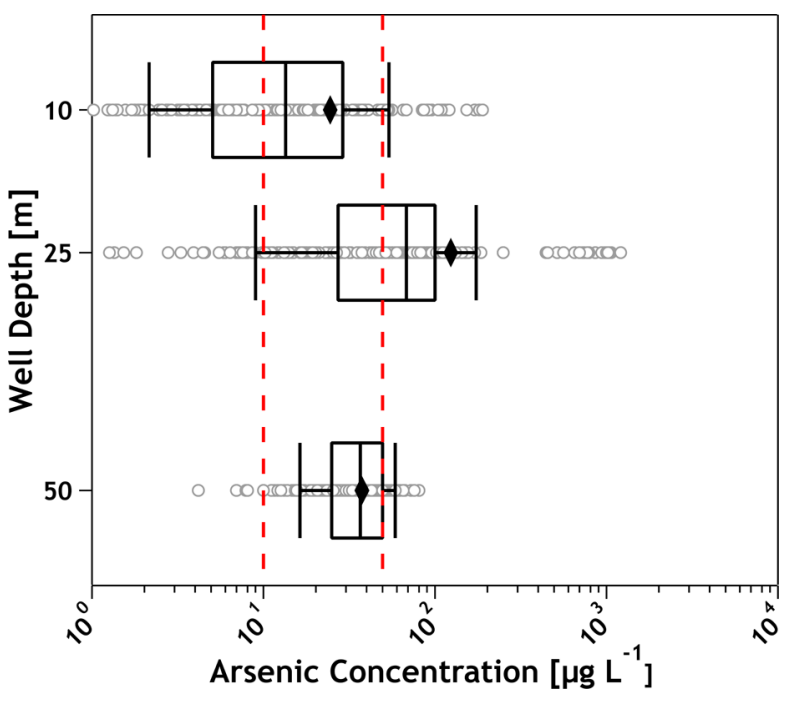

Figure 3. Arsenic concentration grouped by well depth across the field area. Monthly data are plotted (gray circles) for 13 wells (SY01SY13) at each depth for 31 months (May 2012-August 2014). Data are overlain by box plots where the centerline is the median, box edges are the 25th and 75th percentiles, and the bars are the 10th and 90th percentiles. Filled diamonds represent the mean concentration at each depth. For 10, 25, and $50 \mathrm{~m}$ wells $n=363,357$, and 364 measurements, respectively. Red dashed lines indicate drinking water standards at 10 and $50 \mu \mathrm{g} \mathrm{L}^{-1}$.

(September 2012, July 2013, August 2014). Although the timing and duration of extreme values in As concentrations varied somewhat between years, the ratio of the maximum value to minimum value in each year averaged 9.4, nearly an order of magnitude increase in As concentrations within a given year. The ratios for 2012, 2013, and 2014 were 10.6, 11.1, and 6.6 , respectively.

To quantify the magnitude of the seasonal variation in As concentrations across the field site we grouped data by quarter ${ }^{15}$ and compared the two adjacent quarters of AprilJune (Q2) and July-September (Q3). Similar, albeit less extreme, seasonal variation in As concentrations was observed throughout the field area at all measured depths, and without correcting data for variations in the timing of minimum and peak As concentrations. The average ratio of As concentrations of Q3/Q2 for 2012-2014 across the field site were 2.0 \pm 0.7 , $1.9 \pm 0.3$, and $1.5 \pm 0.3$ for 10,25 , and $50 \mathrm{~m}$ wells, respectively, indicating a $50-100 \%$ increase in As concentrations between these adjacent 3-month periods. Each of the 39 wells showed an increased average As concentration between Q2 and Q3, with an average ratio of 1.8 and a range from 1.1 to 3.8 .

Dissolved Iron and Sulfide. Ferrous-iron and sulfide concentrations show similar seasonality as As concentrations in well SY03 (Figure 4). Aqueous $\mathrm{Fe}^{2+}$ concentrations range from 0.2 to $7.3 \mathrm{mg} \mathrm{L}^{-1}$ in this well and $<0.01$ to $39.8 \mathrm{mg} \mathrm{L}^{-1}$ across the field site. Sulfide concentrations range from $<1$ to $66 \mu \mathrm{g} \mathrm{L}^{-1}$ at the $25 \mathrm{~m}$ well at SY03 and $<1$ to $476 \mu \mathrm{g} \mathrm{L}^{-1}$ across the field site. As the downward gradient from surface water to the aquifer increases in magnitude, concentrations of sulfide decrease sharply followed by a decrease in $\mathrm{Fe}^{2+}$ concentrations (Figure 4$). E_{\mathrm{h}}$ measurements during groundwater recharge increase, indicating relatively oxidizing conditions occurring coincident and consistent with decreases in reduced $\mathrm{Fe}$ and $\mathrm{S}$ species (Figure 4). 


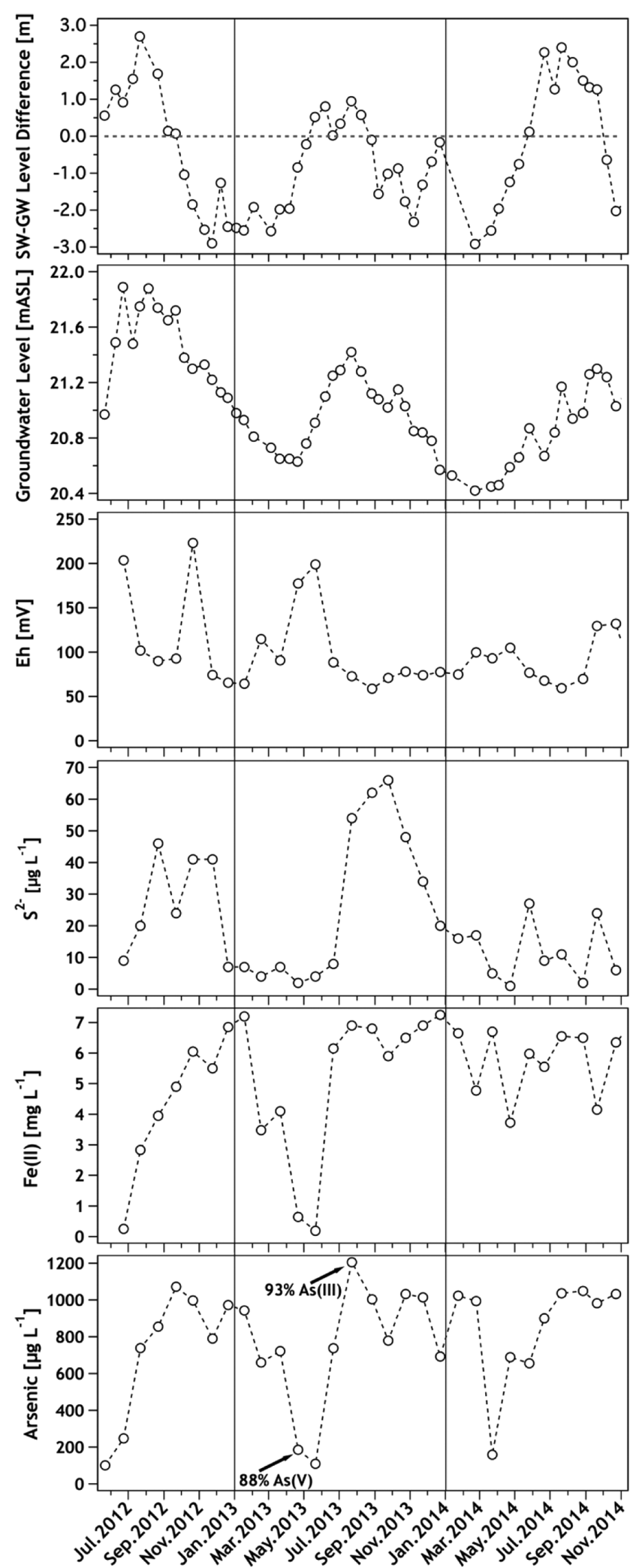

Figure 4. Surface water (SW) and groundwater (GW) level difference, well water level, Eh, dissolved sulfide, $\mathrm{Fe}(\mathrm{II})$, and arsenic at the $25 \mathrm{~m}$ well at SY03 measured from May 2012 to November 2014. Vertical lines are drawn on January 1 of each year for reference.

Sediment Batch Incubations. Anoxic sediment batch incubations in DI water show that As is mobilized from aquifer sands without the addition of exogenous electron donor, and transfer of solid-phase As to the aqueous phase takes place on the order of hours (Figure 5a, SI Figure SI-8). Sediment at 20 $\mathrm{m}$ depth from borehole SY03 releases $11 \mathrm{mg} \mathrm{As} \mathrm{kg}^{-1}$ sediment after 4 days of incubation, whereas sediment from $23 \mathrm{~m}$ releases

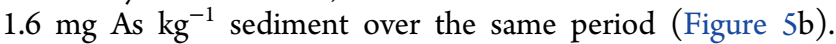
Arsenic release in anoxic DI water incubations is $<0.5 \mathrm{mg}$ As $\mathrm{kg}^{-1}$ sediment at all other depths measured. The solid phase arsenic concentration is $80-100 \mathrm{mg} \mathrm{kg}^{-1}$ from 18 to $20 \mathrm{~m}$ depth, but is $<25 \mathrm{mg} \mathrm{kg}^{-1}$ at all other depths measured in the profile. The carbon content of incubated sediments varied with depth, ranging from $\sim 0.1 \%$ to nearly $2 \%$ (SI Figure SI-9), and dissolved arsenic concentrations varied systematically with aeration during incubation, correlating with changes in redox potential (SI Figure SI-10).

\section{DISCUSSION}

Groundwater chemistry in the Jianghan Plain is influenced by seasonal changes in surface recharge and groundwater flow. The flow gradient shifts annually from surface to groundwater (recharge) from May through September and then to groundwater to surface (discharge) from October through April (Figure 3). The discharging flow gradient from October to April is coincident with the season of lowest precipitation (SI Figure SI-3) and surface water levels, while the reversal to groundwater recharge occurs during the wet season and high surface water levels from May to September. Mixing of surface and groundwater on short time periods is supported by trends in $\delta^{18} \mathrm{O}$ (SI Figure SI-4), temperature (SI Figure SI-6), and $\mathrm{Cl}^{-}$ concentration (SI Figure SI-7) of surface and groundwater.

Based on average hydraulic gradients measured at the field area between wells SY06, 07, 08, and 09, along with a slug test (SI Figure SI-2) determined hydraulic conductivity of $3.1 \times$ $10^{-5} \mathrm{~m} \mathrm{~s}^{-1}$, we estimate an annual horizontal groundwater discharge from the aquifer $(18-50 \mathrm{~m})$ of $51000 \mathrm{~m}^{3}$. This implies a groundwater residence time of 2000-3500 years. Vertical groundwater recharge was also estimated based on the volume of water required to deliver an oxidant $\left(\mathrm{O}_{2}, \mathrm{NO}_{3}\right)$ sufficient to explain observed changes in $\mathrm{Fe}$ (II) concentration. These calculations imply much shorter groundwater residence times of 10-20 years and that the primary source of water to the subsurface is vertical recharge rather than regional horizontal flow (see SI for additional details of these calculations). Water level data during the monitoring period show overall declining water levels in the aquifer (Figure 4, Figure 6) and support groundwater discharge exceeding groundwater recharge, which is potentially driven by groundwater extraction for industrial and/or agricultural use.

Using chloride as a tracer for vertical recharge at the $25 \mathrm{~m}$ well of SY05 (SI Figure SI-7), we similarly calculate a mixing of $0.43 \%$ surface water with groundwater following a spike in surface water chloride in February 2014, although this exchange appears to have occurred over a period of only 1-2 months. At well SY07, which may be influenced a nearby pumping well, changes in chloride concentration indicate that approximately $1 \%$ surface water mixed at $25 \mathrm{~m}$ over a period of $1-2$ months. Extrapolating these mixing results over a 3-6 month period annually, we calculate a residence time of $15-80$ years, similar to residence times calculated from $\mathrm{Fe}$ (II) oxidation estimates. Collectively these results imply that oxygen and nitrate containing surface water is rapidly exchanging with the aquifer on an annual basis and that seasonal changes in water flow between surface and groundwater impart changes to aquifer 

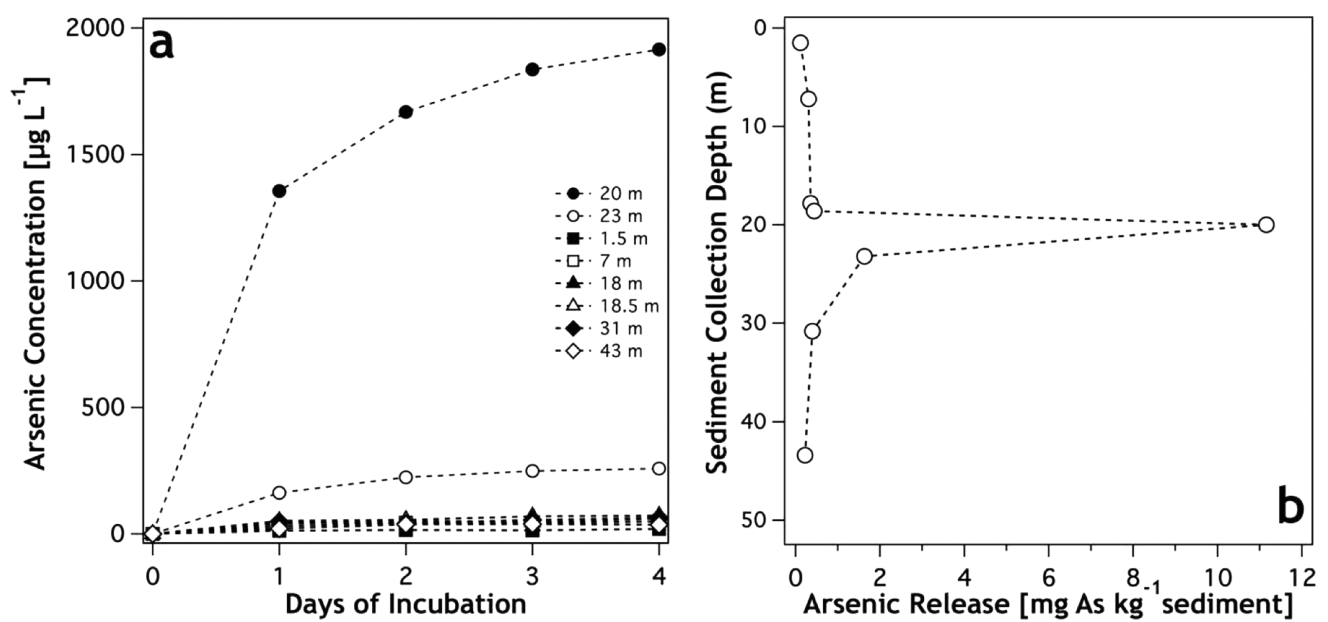

Figure 5. Arsenic released to pore-water for unamended SY03 sediments incubated with deionized water. (a) Rates and (b) extent (after 4 days) of arsenic release from sediment derived from varying depths.

chemistry that include dramatic seasonal shifts in groundwater As concentrations.

Redox Influence on Arsenic Concentrations. Variations in groundwater concentrations of redox active aqueous species correspond to changing water levels and resulting aquifer chemistry. Shifts in aquifer redox conditions arising from seasonal incursion of oxygen and nitrate with surface water are responsible for rapid chemical changes in groundwater. With the onset of recharge of surface water to the aquifer sulfide, $\mathrm{Fe}(\mathrm{II})$, and As concentrations decrease sequentially in the $25 \mathrm{~m}$ well at SY03 (Figure 4), consistent with the predicted sequential oxidative transition of the $\mathrm{HAsO}_{4}{ }^{2-} / \mathrm{H}_{3} \mathrm{AsO}_{3}$, $\mathrm{Fe}(\mathrm{OH})_{3} / \mathrm{Fe}^{2+}$, and $\mathrm{SO}_{4}{ }^{2-} / \mathrm{HS}^{-}$couples. The species concentration profiles indicate a gradual (period of months) shift to more oxidizing conditions as water levels decrease between October and April. During this period, aqueous concentrations of sulfide, $\mathrm{Fe}(\mathrm{II})$, and As diminish, reaching minima in April and May.

However, the oxidizing conditions are transient. As surface water levels fall and the flow gradient reverses, As, along with reduced species of $\mathrm{Fe}$ and $\mathrm{S}$, reappear in solution (Figure 4). Similar observations of As seasonality were made in the Red River Delta where "the highest arsenic concentrations occurred at the transition of the rainy season to the dry season (September, December) and the lowest at the end of the dry season (May)". ${ }^{17}$ In our monthly data set, Fe(II) concentrations increase abruptly between May and June, followed by sulfide and As concentrations between June and July. Aqueous As speciation for May and August revealed that during the period of low As concentrations, As $(\mathrm{V})$ is the dominant species (88\%); a rapid transition to As(III) (93\%) then occurs as total As concentrations increase (Figure 4). These results are consistent with $\mathrm{As}(\mathrm{V})$ and $\mathrm{Fe}(\mathrm{III})$ reduction leading to increased desorption, ${ }^{32}$ and consistent with observations throughout South and Southeast Asia where elevated As concentrations prevail under $\mathrm{As}(\mathrm{V}) / \mathrm{Fe}(\mathrm{III})$ reducing conditions. ${ }^{33,34}$ Incubation experiments indicate that sediments from depths 20-23 m release As appreciably during anoxic incubations without the need for an exogenous electron donor (organic carbon) or more reactive iron hydroxides (Figure 5) and respond rapidly to changes in oxygenation (SI Figure SI10). Our observations of reductive release of arsenic at depth stands in contrast to results from other regions of South and
Southeast Asia where As release is often constrained to surface sediments. ${ }^{19,35-37}$ The absence of arsenic release from deep sediments at these other sites is attributed to the limited reactivity of both the organic carbon and specific arsenicbearing iron oxide. ${ }^{19,35,37}$ The rapid release of arsenic from the sediments at depth here may be attributed to more reactive carbon or, alternatively, more reactive iron oxides produced by the seasonal oxidation.

Controls on Arsenic Concentration. The magnitude of seasonal changes in As concentrations varies with depth and across the site. To provide a means of comparing relative changes in As concentration, thus overcoming the challenge of observing trends comparing highly contaminated wells (e.g., SY03 maximum As concentration $1200 \mu \mathrm{g} \mathrm{L}^{-1}$ ) and less contaminated wells (e.g., SY11 maximum As concentration 54 $\left.\mu \mathrm{g} \mathrm{L}^{-1}\right)$, we calculated a normalized As concentration at individual wells (eq 1 ):

$$
[\text { As }]_{t, \text { norm }}=[\text { As }]_{\mathrm{t}} / \operatorname{MAX}[\text { As }]
$$

Where $[\mathrm{As}]_{t, \text { norm }}$ is the normalized concentration at time $t$, $[\mathrm{As}]_{\mathrm{t}}$ is the measured concentration at time $t$, and $\operatorname{MAX}[\mathrm{As}]$ is the maximum concentration observed at each well over the entire monitoring period ( 31 months). The normalized value at each well has a maximum of unity, corresponding to the time of maximum concentration. We performed a similar normalization for $\mathrm{Fe}(\mathrm{II})$ and sulfide concentrations making it possible to compare the timing of relative changes for the redox active species across the entire field site for the full monitoring period (Figure 6). We analyzed changes in concentrations of As, $\mathrm{Fe}(\mathrm{II})$, and sulfide in relation to recharge and discharge gradients across the site as well as similarly normalized groundwater levels. During periods of groundwater recharge, oxidizing water reaches the subsurface and aqueous concentrations of reduced species decrease (Figure 7A). During periods of groundwater decline and limited recharge from the surface, the supply of oxidizing water is limited and reducing conditions prevail; this leads to increased concentrations of aqueous $\mathrm{As}, \mathrm{Fe}(\mathrm{II})$, and sulfide (Figure $7 \mathrm{~B}$ ).

Inflow of surface water containing low concentrations of As could also dilute As concentrations in the aquifer, but the volume of water required to dilute As concentrations are not supported by groundwater residence times or estimates of vertical recharge (see SI for details of these calculations), nor is 


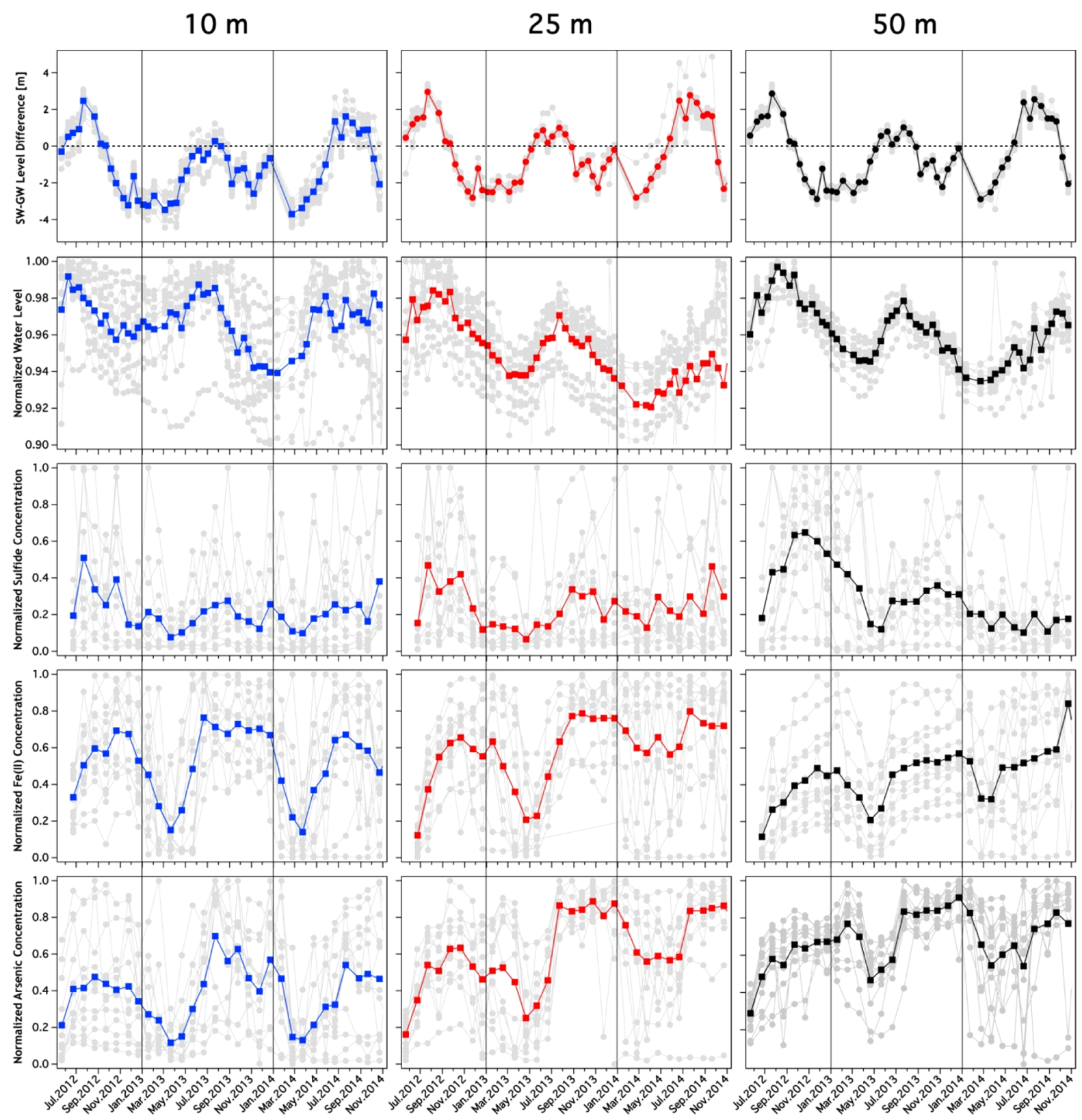

Figure 6. Surface water (SW) and groundwater (GW) level difference, normalized water level, sulfide, ferrous iron, and arsenic concentrations at 10 (blue), 25 (red), and 50 (black) $\mathrm{m}$ wells. Dark squares are the average of all values for each sampling time ( $n=13$ for each well depth) and light gray circles are normalized data from individual wells. Vertical lines are drawn on January 1 of each year for reference.

it consistent with the observed stable isotope trends (SI Figure SI-4). Nonetheless, dilution could contribute to decreases in As concentrations during groundwater recharge. Phosphate seepage into the aquifer resulting from phosphate addition to agricultural fields could also destabilize adsorbed As, but phosphate concentrations are below detectable levels in the aquifer (data not shown), and dissolved phosphate concentrations are typically regulated by strong adsorption on surface soils/sediments. Further, if phosphate induced desorption of As were the major mechanism of As release, we would expect an increase in As concentrations to be independent of, or precede, $\mathrm{Fe}(\mathrm{II})$ concentrations, which is not the case (Figures 4 and 6). Changes in the direction of water flow gradient precede changes in redox conditions and ultimately control As concentrations in the aquifer.

\section{IMPLICATIONS FOR WELL TESTING AND IRRIGATION}

Using the complete data set of more than 1000 As measurements at the field site, we estimated how seasonal variability in As concentrations affects As testing. The worstcase scenario is for false-negative reporting where a test result is safe while in fact the water does not meet drinking water standards. We calculated the rate of false-negative testing if wells are sampled in April, May, or June to be $10 \%$ using the 10 $\mu \mathrm{g} \mathrm{L}^{-1}$ standard and $45 \%$ for the $50 \mu \mathrm{g} \mathrm{L}^{-1}$ standard (Table SI1 , see SI for additional details). This complicates screening large numbers of wells to determine where safe drinking water is reliably available because well screening campaigns in the Jianghan Plain should also consider the season of testing, or allocate resources for retesting. When retesting takes place, we know of no existing guidelines for capturing seasonal variability 

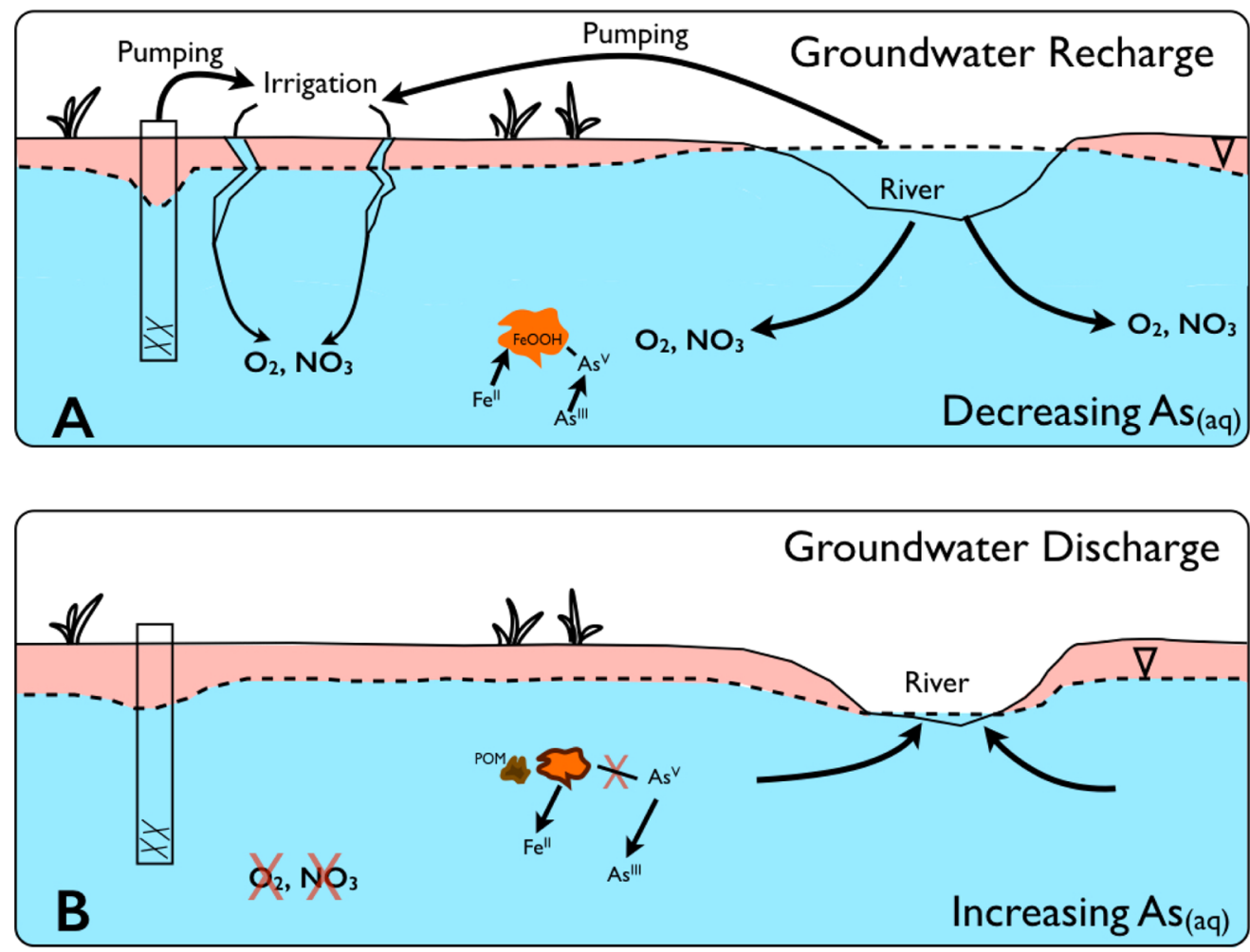

Figure 7. Schematic representation of groundwater flowpaths and major chemical reactions affecting As concentrations during seasonal hydrologic changes. During groundwater recharge (A), oxygenated surface water is delivered to the aquifer either directly from surface water bodies or through fracture flow from the surface through the clay cap. Pumping intensifies local hydraulic gradients by lowering aquifer water levels and draws more oxygen into the aquifer. During this period, $\mathrm{Fe}(\mathrm{II})$ and $\mathrm{As}(\mathrm{III})$ are oxidized, causing aqueous As concentrations to decrease. During groundwater discharge (B), flow gradients reverse and do not permit infiltration of oxygenated surface water into the aquifer. During this period, Fe(III) and $\mathrm{As}(\mathrm{V})$ reduction occur coupled to native particulate organic matter (POM), elevating aqueous As concentrations in the aquifer.

in As concentrations. The rapid response of As concentrations to changes in surface-groundwater gradients implies that human alterations due to irrigation extraction or changes to surface water flow upstream may rapidly increase or decrease groundwater As concentrations and that testing must account for the potential (rapid) shifts in the responding arsenic concentration.

\section{ASSOCIATED CONTENT}

\section{S Supporting Information}

The Supporting Information is available free of charge on the ACS Publications website at DOI: 10.1021/acs.est.5b04986.

Additional information as noted in the text (PDF)

\section{AUTHOR INFORMATION}

\section{Corresponding Author}

*E-mail: fendorf@stanford.edu.

\section{Notes}

The authors declare no competing financial interest.

\section{ACKNOWLEDGMENTS}

This work was funded by the National Natural Science Foundation of China (No. 41521001, No. 41120124003, and No. 41102153), the China Geological Survey (No. 1212011121142), and the Chinese Ministry of Science and Technology (2012AA062602). Portions of this work were also supported by the U.S. National Science Foundation (grant number EAR-0952019), a U.S. National Science Foundation Graduate Research Fellowship Program Grant No. DGE-
114747 awarded to M.V. Schaefer, and the EVP program of Stanford's Woods Institute. We thank Dr. Guangchao Li, Dr. Yiqun Gan, Dr. Xinxin Guo, Dr. Jason Stuckey, Doug Turner, and many staff and students at China University of Geoscience-Wuhan for help with fieldwork and facilitating this study.

\section{REFERENCES}

(1) Smith, A. H.; Hopenhayn-Rich, C.; Bates, M. N.; Goeden, H. M.; Hertz-Picciotto, I.; Duggan, H. M.; Wood, R.; Kosnett, M. J.; Smith, M. T. Cancer risks from arsenic in drinking water. Environ. Health Perspect. 1992, 97, 259-267.

(2) Chen, Y.; Graziano, J. H.; Parvez, F.; Liu, M.; Slavkovich, V.; Kalra, T.; Argos, M.; Islam, T.; Ahmed, A.; Rakibuz-Zaman, M.; et al. Arsenic exposure from drinking water and mortality from cardiovascular disease in Bangladesh: prospective cohort study. BMJ. 2011, 342, d2431.

(3) Kozul, C. D.; Ely, K. H.; Enelow, R. I.; Hamilton, J. W. Low-Dose Arsenic Compromises the Immune Response to Influenza A Infection in Vivo. Environ. Health Perspect. 2009, 117 (9), 1441-1447.

(4) Fendorf, S.; Michael, H. A.; van Geen, A. Spatial and Temporal Variations of Groundwater Arsenic in South and Southeast Asia. Science 2010, 328 (5982), 1123-1127.

(5) Smedley, P. L.; Kinniburgh, D. G. A review of the source, behaviour and distribution of arsenic in natural waters. Appl. Geochem. 2002, 17 (5), 517-568.

(6) Guillot, S.; Charlet, L. Bengal arsenic, an archive of Himalaya orogeny and paleohydrology. J. Environ. Sci. Health, Part A: Toxic/ Hazard. Subst. Environ. Eng. 2007, 42 (12), 1785-1794.

(7) Cummings, D. E.; Caccavo, F.; Fendorf, S.; Rosenzweig, R. F. Arsenic mobilization by the dissimilatory Fe (III)-reducing bacterium Shewanella alga BrY. Environ. Sci. Technol. 1999, 33 (5), 723-729. 
(8) Islam, F. S.; Gault, A. G.; Boothman, C.; Polya, D. A.; Charnock, J. M.; Chatterjee, D.; Lloyd, J. R. Role of metal-reducing bacteria in arsenic release from Bengal delta sediments. Nature 2004, 430 (6995), 68-71.

(9) Yu, G.; Sun, D.; Zheng, Y. Health effects of exposure to natural arsenic in groundwater and coal in China: an overview of occurrence. Environ. Health Perspect. 2007, 115 (4), 636.

(10) He, J.; Charlet, L. A review of arsenic presence in China drinking water. J. Hydrol. 2013, 492 (0), 79-88.

(11) Rodríguez-Lado, L.; Sun, G.; Berg, M.; Zhang, Q.; Xue, H.; Zheng, Q; Johnson, C. A. Groundwater Arsenic Contamination Throughout China. Science 2013, 341 (6148), 866-868.

(12) Sun, G. Arsenic contamination and arsenicosis in China. Toxicol. Appl. Pharmacol. 2004, 198 (3), 268-271.

(13) Wen, D.; Zhang, F.; Zhang, E.; Wang, C.; Han, S.; Zheng, Y. Arsenic, fluoride and iodine in groundwater of China. J. Geochem. Explor. 2013, 135 (0), 1-21.

(14) Gan, Y.; Wang, Y.; Duan, Y.; Deng, Y.; Guo, X.; Ding, X. Hydrogeochemistry and arsenic contamination of groundwater in the Jianghan Plain, central China. J. Geochem. Explor. 2014, 138, 81-93.

(15) Ayotte, J. D.; Belaval, M.; Olson, S. A.; Burow, K. R.; Flanagan, S. M.; Hinkle, S. R.; Lindsey, B. D. Factors affecting temporal variability of arsenic in groundwater used for drinking water supply in the United States. Sci. Total Environ. 2015, 505, 1370-1379.

(16) Gassert, F.; Luo, T.; Shiao, T.; Luck, M. Yangtze River Basin Study; Working Paper; World Resources Institute: Washington D.C., 2013

(17) Nadakavukaren, J. J.; Ingermann, R. L.; Jeddeloh, G.; Falkowski, S. J. Seasonal variation of arsenic concentration in well water in Lane County, Oregon. Bull. Environ. Contam. Toxicol. 1984, 33 (1), 264269.

(18) Berg, M.; Tran, H. C.; Nguyen, T. C.; Pham, H. V.; Schertenleib, R.; Giger, W. Arsenic contamination of groundwater and drinking water in Vietnam: A human health threat. Environ. Sci. Technol. 2001, 35 (13), 2621-2626.

(19) Polizzotto, M. L.; Kocar, B. D.; Benner, S. G.; Sampson, M.; Fendorf, S. Near-surface wetland sediments as a source of arsenic release to ground water in Asia. Nature 2008, 454 (7203), 505-U5.

(20) Benner, S. G.; Polizzotto, M. L.; Kocar, B. D.; Ganguly, S.; Phan, K.; Ouch, K.; Sampson, M.; Fendorf, S. Groundwater flow in an arsenic-contaminated aquifer, Mekong Delta, Cambodia. Appl. Geochem. 2008, 23 (11), 3072-3087.

(21) Thundiyil, J. G.; Yuan, Y.; Smith, A. H.; Steinmaus, C. Seasonal variation of arsenic concentration in wells in Nevada. Environ. Res. 2007, 104 (3), 367-373.

(22) Cheng, Z.; van Geen, A.; Seddique, A. A.; Ahmed, K. M. Limited Temporal Variability of Arsenic Concentrations in 20 Wells Monitored for 3 Years in Araihazar, Bangladesh. Environ. Sci. Technol. 2005, 39 (13), 4759-4766.

(23) Guo, H.; Zhang, Y.; Jia, Y.; Zhao, K.; Li, Y.; Tang, X. Dynamic behaviors of water levels and arsenic concentration in shallow groundwater from the Hetao Basin, Inner Mongolia. J. Geochem. Explor. 2013, 135 (0), 130-140.

(24) Michael, H. A.; Voss, C. I. Evaluation of the sustainability of deep groundwater as an arsenic-safe resource in the Bengal Basin. Proc. Natl. Acad. Sci. U. S. A. 2008, 105 (25), 8531-8536.

(25) Burgess, W. G.; Hoque, M. A.; Michael, H. A.; Voss, C. I.; Breit, G. N.; Ahmed, K. M. Vulnerability of deep groundwater in the Bengal Aquifer System to contamination by arsenic. Nat. Geosci. 2010, 3 (2), $83-87$.

(26) McArthur, J. M.; Banerjee, D. M.; Sengupta, S.; Ravenscroft, P.; Klump, S.; Sarkar, A.; Disch, B.; Kipfer, R. Migration of As, and 3H/ $3 \mathrm{He}$ ages, in groundwater from West Bengal: Implications for monitoring. Water Res. 2010, 44 (14), 4171-4185.

(27) Duan, Y.; Gan, Y.; Wang, Y.; Deng, Y.; Guo, X.; Dong, C. Temporal variation of groundwater level and arsenic concentration at Jianghan Plain, central China. J. Geochem. Explor. 2015, 149, 106-119.
(28) Fang, J.; Rao, S.; Zhao, S. Human-induced long-term changes in the lakes of the Jianghan Plain, Central Yangtze. Front. Ecol. Environ. 2005, 3 (4), 186-192.

(29) Kinniburgh, D. G.; Smedley, P. L. Arsenic contamination of groundwater in Bangladesh http://nora.nerc.ac.uk/11986/ (accessed December 4, 2014).

(30) Harvey, C. F.; Swartz, C. H.; Badruzzaman, A. B. M.; KeonBlute, N.; Yu, W.; Ali, M. A.; Jay, J.; Beckie, R.; Niedan, V.; Brabander, D.; et al. Arsenic mobility and groundwater extraction in Bangladesh. Science 2002, 298 (5598), 1602-1606.

(31) van Geen, A.; Zheng, Y.; Versteeg, R.; Stute, M.; Horneman, A.; Dhar, R.; Steckler, M.; Gelman, A.; Small, C.; Ahsan, H.; et al. Spatial variability of arsenic in 6000 tube wells in a $25 \mathrm{~km} 2$ area of Bangladesh. Water Resour. Res. 2003, 39 (5), 1140.

(32) Tufano, K. J.; Reyes, C.; Saltikov, C. W.; Fendorf, S. Reductive Processes Controlling Arsenic Retention: Revealing the Relative Importance of Iron and Arsenic Reduction. Environ. Sci. Technol. 2008, 42 (22), 8283-8289.

(33) Nickson, R.; McArthur, J.; Burgess, W.; Ahmed, K. M.; Ravenscroft, P.; Rahman, M. Arsenic poisoning of Bangladesh groundwater. Nature 1998, 395 (6700), 338-338.

(34) van Geen, A.; Rose, J.; Thoral, S.; Garnier, J. M.; Zheng, Y.; Bottero, J. Y. Decoupling of As and $\mathrm{Fe}$ release to Bangladesh groundwater under reducing conditions. Part II: Evidence from sediment incubations 1. Geochim. Cosmochim. Acta 2004, 68 (17), $3475-3486$

(35) Stuckey, J. W.; Schaefer, M. V.; Kocar, B. D.; Benner, S. G.; Fendorf, S. Arsenic release metabolically limited to permanently watersaturated soil in Mekong Delta. Nat. Geosci. 2016, 9 (1), 70-76.

(36) Polizzotto, M. L.; Harvey, C. F.; Sutton, S. R.; Fendorf, S. Processes conducive to the release and transport of arsenic into aquifers of Bangladesh. Proc. Natl. Acad. Sci. U. S. A. 2005, 102 (52), 18819-18823.

(37) Kocar, B. D.; Polizzotto, M. L.; Benner, S. G.; Ying, S. C.; Ung, M.; Ouch, K.; Samreth, S.; Suy, B.; Phan, K.; Sampson, M.; et al. Integrated biogeochemical and hydrologic processes driving arsenic release from shallow sediments to groundwaters of the Mekong delta. Appl. Geochem. 2008, 23 (11), 3059-3071. 